JMPF Vol. 9 No. $3: 213-224$

ISSN-p : 2088-8139

ISSN-e : 2443-2946

DOI : $10.22146 / j m p f .47915$

\title{
Evaluasi Luaran Klinis Terapi Antibiotik pada Pasien Community Acquired Pneumonia Anak Rawat Inap
}

\author{
Clinical Outcome Evaluation of Antibiotics Therapy in Community Acquired Pneumonia Inpatient \\ Children
}

\author{
Sabrina Handayani Tambun ${ }^{1}$, Ika Puspitasari ${ }^{2^{*}}$, Ida Safitri ${ }^{3}$ \\ 1. Magister Farmasi Klinik, Fakultas Farmasi UGM,Yogyakarta \\ 2. Departemen Farmakologi dan Farmasi Klinik, Fakultas Farmasi UGM, Yogyakarta \\ 3. Divisi Infeksi dan Tropis Departemen IKA Fakultas Kedokteran UGM/ RSUP DR. Sardjito, Yogyakarta \\ Submitted: 7-20-2019 Revised: 9-24-2019 \\ Accepted: 9-25-2019
}

Korespondensi : Ika Puspitasari : Email : ika.puspitasari@gmail.com

\begin{abstract}
ABSTRAK
Community Acquired Pneumonia (CAP) merupakan penyakit infeksi yang menjadi salah satu penyebab utama kematian anak di negera berkembang. Pola pemberian antibiotik di rumah sakit biasanya masih berdasarkan empiris. Penggunaan antibiotik yang tidak tepat berisiko menyebabkan kegagalan terapi atau resistensi bakteri. Penelitian ini bertujuan untuk mengetahui rasionalitas pemberian antibiotik empiris dan hubungannya terhadap luaran klinis pasien anak dengan CAP di bangsal rawat inap RSUP Dr. Sardjito Yogyakarta. Penelitian menggunakan rancangan deskriptif analitik dengan desain cohort retrospektif. Subyek penelitian adalah pasien anak didiagnosis CAP yang dirawat di bangsal rawat inap anak RSUP Dr. Sardjito Yogyakarta periode 1 Januari - 31 Desember 2018. Rasionalitas antibiotik empiris dievaluasi menggunakan metode Gyssens. Luaran klinis yang diamati berupa parameter kondisi klinis membaik dan belum membaik menurut klinisi yang tercantum pada rekam medis. Analisis data dilakukan secara deskriptif untuk karakteristik pasien, pola penggunaan dan rasionalitas antibiotik empiris,sedangkan uji Chi-square untuk melihat hubungan rasionalitas antibiotik empiris terhadap luaran klinis. Hasil penelitian menunjukkan terdapat 73 pasien yang memenuhi kriteria inklusi dan ekslusi (132 regimen antibiotik empiris). Sebanyak 76,5\% regimen terapi antibiotik empiris memenuhi kategori rasional (kategori 0). Jenis ketidakrasionalan yang terjadi yaitu kategori IIIB 5,3\% dan kategori IIA 18,2\%. Analisis Chi- square menunjukkan rasionalitas antibiotik empiris meningkatkan luaran klinis pasien CAP anak secara bermakna ( $p=0,011 ; O R=2,957 ; 95 \% \mathrm{Cl}=1,263-6,923)$.
\end{abstract}

Kata kunci: antibiotik empiris ; CAP ; luaran klinis ; rasionalitas

\section{ABSTRACT}

Community Acquired Pneumonia (CAP) is an infectious disease which is one of the main causes of child mortality in developing countries. The pattern of giving antibiotics at the hospital is usually still empirical. Inappropriate use of antibiotics may cause failure of therapy or bacterial resistance. This study aims to determine the empirical antibiotic rationality and the relationship of rationality to the clinical outcome of CAP-pediatric inpatients at RSUP. Dr. Sardjito Yogyakarta. The study conducted using a descriptive analytic method with a retrospective cohort design. The subjects were CAP-pediatric inpatients at RSUP. Dr. Sardjito Yogyakarta period 1 January-31 December 2018. The rationality of empirical antibiotics is evaluated using the Gyssens algorithm. The clinical outcome was either good or bad outcome according to the clinician stating in the medical record. Patient characteristics, empirical antibiotic therapy and rationality patterns were analyzed descriptively. The relationship between empirical antibiotic rationality and clinical outcome were evaluated using Chi square test. There were 73 patients who met the inclusion and exclusion criteria (132 empirical antibiotic regimens). Rational antibiotic therapy accounted $76.5 \%$ (category 0 ). Types of irrationality of antibiotic found were IIIB (5.3\%) and IIA categories (18.2\%). Chi-square analysis showed that empirical antibiotic rationality related to good clinical outcome of CAP children ( $p=0.011 ; \mathrm{OR}=2.957 ; 95 \% \mathrm{Cl}=1,263-6,923$ ).

Keywords: CAP; clinical outcome; empirical antibiotics; rationality of antibiotics

\section{PENDAHULUAN}

Pneumonia merupakan infeksi akut pada jaringan parenkim paru atau alveoli yang disebabkan oleh bakteri, virus, jamur, pajanan bahan kimia atau kerusakan fisik dari paru maupun pengaruh tidak langsung dari 
penyakit lain. Gejala yang biasa timbul pada pneumonia yaitu demam, menggigil, sakit kepala, batuk berdahak dan sesak napas. Community Acquired Pneumonia (CAP) merupakan jenis pneumonia yang diperoleh di masyarakat atau terjadi dalam waktu kurang dari 48 jam setelah pasien dirawat di rumah sakit. CAP merupakan jenis pneumonia yang paling sering terjadi $(54,3 \%)^{1-4}$.

Data RISKESDAS tahun 2013 menunjukkan periode prevalensi pneumonia yang tinggi terjadi pada kelompok umur 1 - 4 tahun ${ }^{5}$. CAP merupakan salah satu penyakit infeksi penyebab utama kematian anak kurang dari 5 tahun di negara berkembang ${ }^{6}$. Menurut laporan UNICEF (2016), pada tahun 2015 diperkirakan pneumonia menyebabkan $15 \%$ dari kematian anak kurang dari 5 tahun di dunia. Hal tersebut sesuai dengan data Profil Kesehatan Indonesia tahun 2016, sampai pada tahun 2014 cakupan penemuan pneumonia pada balita berkisar $20-30 \%$, sedangkan pada tahun 2016 mengalami peningkatan menjadi $63,45 \%$.

Prinsip tatalaksana pneumonia yaitu penggunaan antibiotik dengan mempertimbangkan pola kuman, hasil kultur ${ }^{8}$. Pola pemberian antibiotik di rumah sakit biasanya masih berdasarkan empiris. Pada CAP anak penggunaan antibiotik empiris tidak dapat terhindarkan karena adanya tantangan mendiagnosis CAP secara akurat dan sulit untuk mengidentifikasi organisme penyebab ${ }^{9}$. Anak merupakan kelompok usia yang perlu perhatian khusus dalam pemberian obat karena perbedaan fisiologis yang dapat memengaruhi proses absorpsi, distribusi, metabolisme dan ekskresi obat serta konsentrasi obat dalam plasma atau jaringan ${ }^{10,11}$. Penggunaan antibiotik yang kurang tepat dapat menyebabkan resistensi bakteri. Kejadian resistensi antibiotik yang meningkat menjadi penyebab perparahan infeksi, terjadi komplikasi penyakit, waktu rawat dirumah sakit menjadi lebih panjang serta peningkatan beban biaya pelayanan kesehatan. Penggunaan antibiotik yang rasional untuk mengurangi risiko resistensi merupakan tanggungjawab bersama tenaga kesehatan. Upaya yang dapat dilakukan yaitu evaluasi penggunaan antibiotik dirumah sakit ${ }^{12-14}$. Penelitian terkait evaluasi penggunaan antibiotik pada pasien pneumonia dewasa di RSUP Dr. Sardjito sudah pernah dilakukan oleh beberapa peneliti dengan variasi outcome klinis yang muncul setelah terapi antibiotik, sedangkan evaluasi penggunaan antibiotik pada pasien CAP anak belum pernah dilakukan di RSUP Dr. Sardjito. Oleh karena itu, penelitian ini bertujuan untuk mengetahui rasionalitas antibiotik dan hubungan rasionalitas antibiotik terhadap luaran klinis pasien anak CAP di rawat inap RSUP Dr. Sardjito Yogyakarta. Penelitian ini perlu dilakukan karena pada waktu dan populasi yang berbeda dimungkinkan terdapat perbedaan pola kuman dan sensitivitasnya terhadap antibiotik. Kelompok yang dipilih adalah anak karena berdasarkan pustaka angka kejadian dan kematian akibat pneumonia pada anak cukup tinggi ${ }^{6,7}$.

\section{METODE}

Penelitian ini merupakan penelitian deskriptif analitik menggunakan desain kohort retrospektif yang dilakukan di Instalasi Catatan Medik RSUP Dr. Sardjito Yogyakarta. Pengambilan sampel dilakukan secara purposive sampling berdasarkan data rekam medis pasien anak dengan diagnosa CAP dirawat inap RSUP Dr. Sardjito Yogyakarta selama periode 1 Januari - 31 Desember 2018 yang memenuhi kriteria inklusi yaitu anak usia 0 - 18 tahun, dirawat inap dengan diagnosa CAP berdasarkan hasil pemeriksaan klinis dan rontgen toraks spesifik pneumonia sesuai yang tercantum di rekam medis serta pasien memperoleh terapi antibiotik empiris. Antibiotik empiris adalah antibiotik yang diterima pasien anak dengan diagnosa CAP sebelum dilakukan pemeriksaaan kultur sensitvitas bakteri. Kriteria eksklusi yaitu pasien pulang paksa atau meninggal dunia kurang dari 48 jam perawatan di rumah sakit. Subyek yang memenuhi kriteria inklusi dan ekslusi dilakukan evaluasi rasionalitas 
antibiotik empiris menggunakan kategori Gyssens dengan cara membandingkan terapi yang diperoleh pasien dengan guideline CAP, kemudian dicatat luaran klinisnya. Guideline utama yang digunakan adalah Pedoman Pelayanan Medis oleh IDAI tahun 2009 dan Pelayanan Kesehatan Anak di Rumah Sakit oleh WHO tahun 2009, sesuai dengan acuan yang digunakan di RSUP Dr. Sardjito Yogyakarta. Jika antibiotik yang diberikan tidak tercantum dalam guideline tersebut, maka penelusuran dilanjutkan pada guideline IDSA: The Management of Community Acquired Pneumonia in Infants and Children Older Than 3 Months; ;exicomp Drug Information Handbook $26^{\text {th }}$ Edition 2017-201815; atau Drug Doses Frank Shann $17^{\text {th }}$ Edition. Luaran klinis ditunjukkan dengan kondisi klinis membaik dan belum membaik, ditandai dengan adanya perbaikan klinis menurut klinisi pada hasil rontgen toraks, laju pernapasan dan/atau saturasi oksigen sesuai dengan yang tercantum pada rekam medis.

Analisis data dilakukan secara deskriptif untuk karakteristik pasien, pola penggunaan antibiotik dan rasionalitas antibiotik empiris berdasarkan kategori Gyssens dengan cara data - data tersebut dikelompokkan dan disajikan dalam bentuk persentase. Analisis hubungan rasionalitas antibiotik empiris terhadap luaran klinis menggunakan uji Chi - square dengan interval kepercayaan (CI) 95\%.

\section{HASIL DAN PEMBAHASAN}

\section{Karakteristik Subyek Penelitian}

Pasien CAP anak periode 1 Januari - 31

Desember 2018 yang memenuhi kriteria inklusi dan ekslusi adalah 73 anak dengan jumlah antibiotik empiris sebanyak 132 regimen. Karakteristik subyek dalam penelitian ini disajikan secara deskriptif pada Tabel I meliputi: jenis kelamin, usia, cara masuk rumah sakit, cara pembayaran, ruang perawatan, status gizi, riwayat berat badan lahir, infeksi penyerta penyakit penyerta/ komplikasi non infeksi dan lama rawat inap.

Data karakteristik pasien menunjukkan CAP paling banyak terjadi pada jenis kelamin laki - laki yaitu $63 \%$. Data ini serupa dengan hasil penelitian pneumonia yang dilakukan di West China Second University Hospital ${ }^{11}$. Pneumonia lebih banyak terjadi pada laki laki dapat dimungkinkan karena perbedaan anatomi dan fisiologi pada saat masa kanakkanak. Diameter saluran pernapasan anak laki - laki lebih kecil dibandingkan dengan anak perempuan $^{16,17}$. Data distribusi CAP pada pasien anak berdasarkan kelompok usia yaitu anak usia 2-12 bulan menunjukkan persentase terbesar $47,9 \%$. Hal ini serupa dengan laporan penelitian UNICEF yang menyebutkan kasus pneumonia paling besar terjadi pada anak berusia dibawah 5 tahun ${ }^{6}$. Pasien yang dirawat di RSUP Dr. Sardjito mayoritas merupakan rujukan dari rumah sakit lain $(58,9 \%)$ dan sebanyak $43,8 \%$ pasien menggunakan jaminan JKN non PBI . Pada penelitian ini sebanyak $46,5 \%$ pasien CAP memiliki status gizi kurang. Penelitian Hartati di RSUD Pasar Rebo Jakarta menunjukan hasil terdapat hubungan bermakna antara status gizi dengan pneumonia. Pasien malnutrisi 6,52 kali lebih rentan untuk mengalami pneumonia dibandingkan dengan pasien yang memiliki status gizi baik ${ }^{18}$. Status gizi kurang atau malnutrisi dapat menyebabkan penurunan daya tahan tubuh sehingga meningkatkan faktor risiko pneumonia ${ }^{19}$. Penurunan daya tahan tubuh terjadi karena ketidakseimbangan produksi antibodi yaitu penurunan imunoglobulin A (IgA). IgA pada sistem imun berfungsi untuk melindungi saluran nafas atas dari infeksi organisme patogenik, sehingga penurunan level IgA mengakibatkan penurunan sistem imun saluran nafas sehingga akan memperparah derajat infeksi sistem saluran nafas ${ }^{20,21}$. Pada penelitian ini $26 \%$ pasien CAP dengan riwayat berat badan lahir rendah (BBLR). BBLR merupakan salah satu faktor risiko pneumonia ${ }^{20}$. Anak dengan riwayat BBLR berisiko mengalami infeksi dan masalah pernapasan karena paru yang belum matur serta sistem pertahanan tubuh belum terbentuk sempurna ${ }^{18,22}$.

Penyakit penyerta atau komplikasi juga dapat berpengaruh terhadap prognosis penyakit $\mathrm{CAP}$, bahkan dapat menyebabkan 
Sabrina Handayani Tambun, et al

Tabel I. Karakteristik Pasien CAP Anak di Rawat Inap RSUP Dr. Sardjito Yogyakarta

\begin{tabular}{|c|c|c|}
\hline Karakteristik & $\begin{array}{c}\text { Jumlah } \\
(\mathrm{n}=73)\end{array}$ & $\begin{array}{c}\text { Persentase } \\
(\%)\end{array}$ \\
\hline \multicolumn{3}{|l|}{ Jenis kelamin } \\
\hline Laki-laki & 46 & $63 \%$ \\
\hline Perempuan & 27 & $37 \%$ \\
\hline \multicolumn{3}{|l|}{ Usia } \\
\hline$<2$ bulan & 11 & $15,1 \%$ \\
\hline 2 bulan - 12 bulan & 35 & $47,9 \%$ \\
\hline$>1$ tahun -5 tahun & 24 & $32,9 \%$ \\
\hline$>5$ tahun -18 tahun & 3 & $4,1 \%$ \\
\hline \multicolumn{3}{|l|}{ Cara MRS } \\
\hline Rujukan RS lain & 43 & $58,9 \%$ \\
\hline Datang sendiri & 22 & $30,1 \%$ \\
\hline Rujukan Dokter umum/anak & 5 & $6,8 \%$ \\
\hline Rujukan Puskesmas & 3 & $4,1 \%$ \\
\hline \multicolumn{3}{|l|}{ Cara pembayaran } \\
\hline JKN non PBI & 32 & $43,8 \%$ \\
\hline JKN PBI & 23 & $31,5 \%$ \\
\hline Umum & 14 & $19,2 \%$ \\
\hline Asuransi lain/ Jamkesos/ Jamkesda & 3 & $4,1 \%$ \\
\hline Fasilitas Pegawai & 1 & $1,4 \%$ \\
\hline \multicolumn{3}{|l|}{ Ruang perawatan } \\
\hline Bangsal & 64 & $87,7 \%$ \\
\hline PICU + bangsal & 9 & $12,3 \%$ \\
\hline \multicolumn{3}{|l|}{ Status gizi } \\
\hline Baik & 31 & $42,5 \%$ \\
\hline Kurang & 34 & $46,6 \%$ \\
\hline Buruk & 8 & $11,0 \%$ \\
\hline \multicolumn{3}{|l|}{ Riwayat BBLR } \\
\hline Tidak & 54 & $74 \%$ \\
\hline Iya & 19 & $26 \%$ \\
\hline \multicolumn{3}{|l|}{ Infeksi penyerta } \\
\hline Ada & 14 & $19,2 \%$ \\
\hline Tidak & 59 & $80,8 \%$ \\
\hline \multicolumn{3}{|l|}{ Penyakit penyerta/ komplikasi } \\
\hline Ada & 65 & $89,0 \%$ \\
\hline Tidak & 8 & $11,0 \%$ \\
\hline \multicolumn{3}{|l|}{ Lama Rawat Inap } \\
\hline 3-5 hari & 15 & $20,5 \%$ \\
\hline 6-10 hari & 28 & $38,4 \%$ \\
\hline $11-15$ hari & 20 & $13,7 \%$ \\
\hline$>15$ hari & 10 & $9,1 \%$ \\
\hline
\end{tabular}

Keterangan: MRS : masuk rumah sakit; JKN: Jaminan Kesehatan Nasional; PBI: penerima bantuan iuran; PICU: Pediatric Intensive Care Unit; BBLR: berat badan lahir rendah 
Sabrina Handayani Tambun, et al

Tabel II. Penyakit Penyerta Pasien CAP Anak

\begin{tabular}{lcc}
\hline Penyakit Penyerta/komplikasi & $\begin{array}{c}\text { Jumlah } \\
(\mathbf{n}=73)\end{array}$ & $\begin{array}{c}\text { Persentase } \\
\text { (\%) }\end{array}$ \\
\hline Infeksi & & $7 \%$ \\
Meningoensevalitis & 5 & $5 \%$ \\
Sepsis & 4 & $4 \%$ \\
ISK & 3 & $3 \%$ \\
Ensevalitis viral & 2 & $1 \%$ \\
Pertussis & 1 & $1 \%$ \\
Hospital acquired infection ec P.aeruginosa $\mathcal{E}$ C.tropica & $1 \%$ \\
Diare disentriform & 1 & $32 \%$ \\
Non Infeksi ${ }^{*}$ & 1 & $29 \%$ \\
Kardiovaskular & & $22 \%$ \\
Anemia & 23 & $18 \%$ \\
Gizi buruk/ kurang & 21 & $15 \%$ \\
Global developmental delay & 16 & $14 \%$ \\
Severely underweight/severely stunted & 13 & $14 \%$ \\
Epilepsi & 11 & $12 \%$ \\
Cerebral palsy tetraparse & 10 & $12 \%$ \\
Mikrosefali & 10 & $10 \%$ \\
Failure to thrive & 9 & $7 \%$ \\
Laringo malasia & 9 & \\
Down syndrome & 7 & 5 \\
\hline
\end{tabular}

Keterangan: satu pasien bisa memiliki lebih dari 1 penyakit penyerta; ${ }^{*} 10$ penyakit penyerta yang paling banyak dialami pasien

kematian apabila tidak diterapi dengan tepat ${ }^{23}$. Pasien yang memiliki penyerta infeksi sebanyak 19,2\% (14 pasien). Sedangkan pasien CAP dengan penyerta atau komplikasi penyakit non infeksi memiliki proporsi lebih besar dibanding pasien tanpa penyakit penyerta yaitu $89,0 \% \quad$ (65 pasien). Pada Tabel II ditampilkan penyakit penyerta non infeksi yang paling banyak adalah penyakit kardiovaskular 32\% (23 pasien). Risiko pneumonia meningkat 3 kali lebih besar pada pasien dengan penyakit kardiovaskular ${ }^{24}$.

\section{Profil Penggunaan Antibiotik Empiris pada Pasien CAP anak}

Terapi awal antibiotik pada CAP diberikan secara empiris, hal ini dimungkinkan karena patogen penyebab pneumonia biasanya belum dapat dipastikan saat awal perawatan ${ }^{25}$. Dari 73 pasien yang memenuhi kriteria inklusi diperoleh 132 regimen antibiotik empiris. Berdasarkan Tabel III golongan betalaktam merupakan pilihan terbanyak untuk terapi empiris pada pasien anak. Ampisilin merupakan regimen yang paling banyak diberikan, baik diberikan secara kombinasi antara ampisilin- gentamisin ataupun ampisilin tunggal, yaitu secara berturut - turut 21,2\% dan 17,4\%. Hal ini sesuai dengan Pedoman Pelayanan Medis Ikatan Dokter Anak Indonesia (2009) yang merekomendasikan ampisilin sebagai pilihan pertama antibiotik empiris pada pasien CAP yang dirawat inap. Peneslitian sebelumnya di RSUD Soetomo ${ }^{26}$ dan penelitian di Rumah Sakit Pediatri IMIP Brazil27 menyebutkan hasil yang sama yaitu ampisilin merupakan antibiotik yang paling banyak diresepkan pada pasien anak dengan penyakit pneumonia.

Sefalosporin generasi 3 yang diterima pasien pada penelitian ini yaitu seftriakson, 
Tabel III. Gambaran Penggunaan Antibiotik Empiris pada Pasien CAP Anak

\begin{tabular}{lcc}
\hline Penyakit Penyerta/komplikasi & $\begin{array}{c}\text { Jumlah } \\
(\mathbf{n}=\mathbf{7 3})\end{array}$ & $\begin{array}{c}\text { Persentase } \\
\mathbf{( \% )}\end{array}$ \\
\hline Infeksi & 5 & $7 \%$ \\
Meningoensevalitis & 4 & $5 \%$ \\
Sepsis & 3 & $4 \%$ \\
ISK & 2 & $3 \%$ \\
Ensevalitis viral & 1 & $1 \%$ \\
Pertussis & 1 & $1 \%$ \\
Hospital acquired infection ec P.aeruginosa E.tropica & $1 \%$ \\
Diare disentriform & 1 & $32 \%$ \\
Non Infeksi * & & $29 \%$ \\
Kardiovaskular & 23 & $22 \%$ \\
Anemia & 21 & $18 \%$ \\
Gizi buruk/ kurang & 16 & $15 \%$ \\
Global developmental delay & 13 & $14 \%$ \\
Severely underweight/severely stunted & 11 & $14 \%$ \\
Epilepsi & 10 & $12 \%$ \\
Cerebral palsy tetraparse & 10 & $12 \%$ \\
Mikrosefali & 9 & $10 \%$ \\
Failure to thrive & 9 & $7 \%$ \\
Laringo malasia & 7 & \\
Down syndrome & 5 & \\
\hline
\end{tabular}

Keterangan: satu pasien bisa memiliki lebih dari 1 penyakit penyerta; ${ }^{*} 10$ penyakit penyerta yang paling banyak dialami pasien

seftazidim dan sefiksim. Sefalosporin generasi 3 merupakan lini kedua pada CAP. Sefalosporin generasi 3 memiliki aktivitas luas sehingga mampu melawan bakteri gram negatif maupun positif8,22,28. Antibiotik diberikan secara kombinasi sebanyak 24,2\%. Pemberian kombinasi antibiotik dimaksudkan untuk memperluas spektrum antibiotik dan memberikan efek kerja yang sinergisme serta untuk menghambat terjadinya resistensi. Indikasi penggunaan antibiotik kombinasi yaitu digunakan sebagai terapi empiris pada infeksi berat atau ketika dimungkinkan infeksi disebabkan oleh lebih dari satu bakteri. Hal yang perlu diperhatikan dalam pemilihan kombinasi yaitu antibiotik bekerja pada target yang berbeda dapat meningkatkan atau mengganggu keseluruhan aktivitas antibiotik ${ }^{26,29}$. Kombinasi antibiotik yang banyak digunakan pada penelitian adalah ampisilin-gentamisin (20,9\%). Kombinasi antara ampisilin dan gentamisin memberikan mekanisme kerja sinergis, betalaktam bekerja dengan cara menghambat sintesis dinding sel, sehingga meningkatkan permeabelitas membran yang memfasilitasi difusi aminoglikosida masuk intrasel bakteri menyebabkan sintesis protein bakteri terhambat, meningkatkan aktivitas antibiotik $^{30,31}$. Pemberian gentamisin tunggal kurang efektif karena penetrasi ke jaringan paru kurang baik $^{31}$. Pada regimen terapi antibiotik empiris pasien kadang ditambahkan antibiotik golongan makrolida yaitu azitromisin atau eritromisin. Antibiotik makrolida dipertimbangkan untuk ditambahkan pada terapi betalaktam ketika pasien belum memberikan respons pada terapi antibiotik empiris pertama, jika dimungkinkan pneumonia yang dialami merupakan pneumonia atipikal yang disebabkan oleh C. pneumoniae atau 
M. pneumoniae atau pada pneumonia berat. Antibiotik golongan makrolida merupakan pilihan utaman empiris pada anak usia lebih dari 5 tahun karena infeksi $M$. pneumoniae lebih sering dialami pada anak usia tersebut ${ }^{8,22,32}$. Penelitian lain juga menyebutkan pada pasien rawat jalan CAP usia 6 - 18 tahun yang menerima kombinasi beta laktam dan makrolida menunjukan odds ratio kegagalan terapi yang lebih rendah dibandingkan pasien yang menerima terapi betalaktam tunggal ${ }^{33}$.

Durasi pemberian regimen antibiotik selama rawat inap pada penelitian ini sebagian besar adalah 3 - 5 hari (53,8\%). Durasi terapi pada CAP disesuaikan dengan perjalanan penyakit. Durasi antibiotik yang disarankan untuk CAP yaitu 5 - 10 hari disesuaikan dengan perbaikan klinis pasien ${ }^{8,34}$. Pada pneumonia yang dimungkinkan akibat bakteri atipikal rekomendasi terapi antibiotik adalah 10 - 14 hari $^{35}$. Pada penelitian terdapat dua kasus pemberian regimen antibiotik lebih dari 14 hari yaitu selama 15 hari dan 16 hari, pasien memiliki infeksi penyerta meningoensevalitis sehingga durasi yang dibutuhkan lebih panjang. Durasi antibiotik pada meningoensevalitis diberikan selama $14-21$ hari $^{15}$.

Rute antibiotik yang paling banyak diberikan adalah intravena (78,0\%). Antibiotik diberikan secara intravena ketika pasien tidak dapat menerima antibiotik peroral misal karena muntah atau pada pneumonia dengan kondisi klinis berat ${ }^{22,32}$. Pada penelitian ini penggunaan antibiotik oral sebanyak 19,7\%. Antibiotik peroral biasanya diberikan sebagai terapi subtitusi ketika kondisi klinis pasien sudah membaik secara stabil dengan menggunakan antibiotik yang memiliki spektrum mikroorganisme sama. Hal tersebut berkaitan efektivitas biaya dan agar pasien bisa melanjutkan terapi dirumah 22,23,25,30.

\section{Evaluasi Rasionalitas Penggunaan Antibiotik Empiris Pada CAP}

Pada CAP perbaikan klinis akan terlihat setelah 48 - 72 jam pemberian antibiotik empiris, jika antibiotik yang diterima adekuat. Pemilihan antibiotik empiris perlu mempertimbangkan epidemiologi CAP berkaitan dengan pola bakteri dan resistensinya, usia, keparahan penyakit serta kemampuan antibiotik mencapai tempat infeksi dalam kadar yang memadai22,27,36. Terapi antibiotik empiris yang tidak efektif dapat disebabkan oleh pemilihan antibiotik yang tidak rasional, resistensi terhadap antibiotik yang diberikan dan terjadi komplikasi ${ }^{25}$. Pada penelitian ini tidak dilakukan evaluasi rasionalitas terkait harga (kategori IVc), karena penelitian dilakukan retrospektif dengan hanya melihat data rekam medis dimana setiap antibiotik yang digunakan untuk terapi CAP pada rekam medis ditulis menggunakan nama generiknya sehingga evaluasi kategori IVc tidak dapat dilakukan. Antibiotik dikatakan rasional jika berada pada kategori 0 . Hasil evaluasi rasionalitas kategori Gyssens (Tabel IV) menunjukkan antibiotik rasional sebanyak $76,5 \%$ (101 regimen), sedangkan antibiotik yang tidak rasional 23,5\% (31 regimen). Kategori antibiotik tidak rasional yang ditemui yaitu kategori IIIB (pemberian terlalu singkat) sebanyak 5,3\% dan kategori IIA (dosis antibiotik tidak sesuai) 18,2\%. Pemberian dosis yang tidak sesuai terutama berkaitan dengan kurangnya dosis serta durasi pemberian yang terlalu singkat berisiko menyebabkan tujuan terapi tidak tercapai dan terjadi resistensi ${ }^{37}$. Ketidakrasionalan pemberian antibiotik yang paling banyak terjadi adalah pada kategori IIa berkaitan dengan dosis. Secara umum untuk penetapan antibiotik empiris untuk CAP anak, klinisi telah melakukan penyesuaian dosis berdasarkan berat badan dan usia anak, namun masih terdapat kasus ketidakrasionalan pada dosis terapi. Ketidakrasioanalan kategori IIIB berkaitan dengan pemberian yang terlalu singkat yaitu kurang dari 48 jam. Pada pemberian terapi antibiotik empiris untuk CAP evaluasi hasil pengobatan dan perbaikan klinis diamati setelah 48- 72 jam terapi ${ }^{8,36}$. 
Tabel IV. Evaluasi Rasionalitas Antibiotik berdasarkan Kategori Gyssens

\begin{tabular}{lc}
\hline \multicolumn{1}{c}{ Kategori Rasionalitas Antibiotik } & $\begin{array}{c}\text { Regimen Antibiotik } \\
\mathbf{n = 1 3 2} \mathbf{( \% )}\end{array}$ \\
\hline Rasional & $\mathbf{1 0 1} \mathbf{( 7 6 , 5 )}$ \\
Kategori 0 & $\mathbf{3 1}(\mathbf{2 3 , 5 )}$ \\
Tidak rasional & 0 \\
Kategori VI (data tidak lengkap) & 0 \\
Kategori V (tidak ada indikas penggunaan antibiotik) & 0 \\
Kategori IVa (ada antibiotik yang lebih efektif) & 0 \\
Kategori IVb (ada antibiotik kurang toksik) & $-*$ \\
Kategori IVc (ada antibiotik yang lebih murah) & 0 \\
Kategori IVd (ada antibiotik lain spektrum lebih sempit) & 0 \\
Kategori IIIa (pemberian antibiotik terlalu lama) & $7(5,3)$ \\
Kategori IIIb (pemberian antibiotik terlalu singkat) & $24(18,2)$ \\
Kategori IIa (dosis tidak sesuai) & 0 \\
Kategori IIb (interval tidak sesuai) & 0 \\
Kategori IIc (rute tidak sesuai) & 0 \\
Kategori I (waktu pemberian tidak tepat) & \\
\hline
\end{tabular}

Keterangan: *tidak dilakukan evaluasi kategori Ivc

Tabel V. Sebaran Penggunaan Antibiotik dan Kategori Gyssens

\begin{tabular}{lcccc}
\hline \multirow{2}{*}{ Antibiotik } & \multicolumn{3}{c}{ Kategori Gyssens } & Jumlah \\
\cline { 2 - 4 } & $\mathbf{0}$ & IIa & IIIb & n= 132 (\%) \\
\hline Ampisilin - gentamisin & 15 & 10 & 3 & $28(21,2)$ \\
Seftriakson - azitromisin & 2 & 0 & 0 & $2(1,5)$ \\
Seftazidim - azitromisin & 1 & 0 & 0 & $1(0,8)$ \\
Sefiksim - azitromisin & 1 & 0 & 0 & $1(0,8)$ \\
Ampisilin & 23 & 0 & 0 & $23(17,4)$ \\
Seftriakson & 23 & 0 & 0 & $23(17,4)$ \\
Sefotaksim & 11 & 2 & 0 & $13(9,8)$ \\
Gentamisin & 6 & 4 & 2 & $12(9,1)$ \\
Sefiksim & 9 & 1 & 0 & $10(7,6)$ \\
Azitromisin & 7 & 0 & 0 & $7(5,3)$ \\
Amoksisilin & 0 & 5 & 1 & $6(4,5)$ \\
Meropenem & 2 & 1 & 1 & $4(3,0)$ \\
Eritromisin & 1 & 1 & 0 & $2(1,5)$ \\
& 101 & 24 & 7 & $132(\mathbf{1 0 0})$ \\
\hline
\end{tabular}

\section{Hubungan Rasionalitas Antibiotik Empiris terhadap Luaran Klinis}

Pada Tabel VI menunjukkan sebanyak 79 regimen yang rasional memberikan luaran klinis yang membaik. Pada kategori IIIB terdapat 1 regimen yang memberikan luaran klinis membaik yaitu pada regimen amoksisilin peroral, luaran klinis yang membaik dapat dikarenakan pasien sudah menerima antibiotik empiris lain sebelumnya hingga klinis pasien membaik dan stabil kemudian dilakukan pernggantian ke antibiotik oral. Kategori IIA menunjukkan sebanyak 16 regimen memberikan luaran klinis membaik, hal ini dapat terjadi karena sifat farmakokinetika antibiotik berkaitan dengan time dependent atau concentration dependent. Pada antibiotik time dependent efek 
Sabrina Handayani Tambun, et al

Tabel VI. Sebaran Rasionalitas dan Luaran Klinis

\begin{tabular}{lcc}
\hline \multicolumn{1}{c}{ Kategori Rasionalitas Antibiotik } & \multicolumn{2}{c}{ Luaran Klinis } \\
\cline { 2 - 3 } & $\begin{array}{c}\text { Baik } \\
\mathbf{n}(\%)\end{array}$ & $\begin{array}{c}\text { Belum Baik } \\
\mathbf{n}(\%)\end{array}$ \\
\hline $\begin{array}{l}\text { Rasional } \\
\text { Kategori 0 }\end{array}$ & $79(78,2)$ & $22(21,8)$ \\
$\begin{array}{l}\text { Tidak rasional } \\
\text { Kategori IIIb (pemberian antibiotik terlalu singkat) }\end{array}$ & $1(14,3)$ & $6(85,7)$ \\
Kategori IIa (dosis tidak sesuai) & $16(66,7)$ & $8(33,3)$ \\
\hline
\end{tabular}

Tabel VII. Hubungan Rasionalitas Antibiotik Empiris terhadap Luaran Klinis

\begin{tabular}{|c|c|c|c|c|c|}
\hline \multirow{2}{*}{$\begin{array}{c}\text { Rasionalitas } \\
\text { antibiotik empiris }\end{array}$} & \multicolumn{2}{|c|}{ Luaran Klinis } & \multirow[b]{2}{*}{$P$} & \multirow[b]{2}{*}{ OR } & \multirow[b]{2}{*}{$95 \% \mathrm{CI}$} \\
\hline & $\begin{array}{l}\text { Baik } \\
\text { n (\%) }\end{array}$ & $\begin{array}{c}\text { Belum Baik } \\
\text { n (\%) }\end{array}$ & & & \\
\hline Rasional & $79(78,2)$ & $22(21,8)$ & $0,011^{*}$ & 2,957 & $1,263-$ \\
\hline
\end{tabular}

Keterangan: OR: Oods Ratio; CI: Confidence Interval; * ${ }^{*}$ ignifikan secara statistik $(\mathrm{p} \leq 0,05)$

antibakteri akan tetap tercapai selama kadarnya berada diatas kadar hambat minimal (KHM). Luaran klinis membaik pada kategori IIA juga dapat terjadi karena regimen tersebut diberikan secara kombinasi, sehingga luaran klinis yang dihasilkan berasal dari salah satu antibiotik yang rasional ${ }^{38}$. Penggunaan antibiotik yang rasional diharapkan meningkatkan luaran klinis. Dari Tabel VII, terdapat hubungan signifikan pemberian antibiotik empiris yang rasional terhadap luaran klinis $(p=0,011 ; O R=2,957$; nilai 95\% $C I=1,263 \quad-6,923)$, sehingga menunjukkan pemberian antibiotik yang rasional meningkatkan luaran klinis. Hasil penelitian luaran klinis pada pneumonia di bangsal anak Rumah Sakit Dr. R. Soetrasno Rembang juga menunjukkan hasil yang sama, penggunaan antibiotik yang rasional memberikan luaran klinis (suhu, laju pernafasan, retraksi, angka leukosit dan neutofil segmen) yang lebih baik secara signifikan dibanding penggunaan antibiotik yang tidak sesuai $(p=0,001)^{39}$.

\section{Hubungan Variabel Perancu terhadap Luaran Klinis}

Variabel perancu yang dianalisis pada penelitian ini yaitu usia, infeksi penyerta, penyakit penyerta non infeksi dan status gizi. Usia kurang dari 5 tahun merupakan faktor risiko tertinggi pneumonia karena sistem imun tubuh masih berkembang ${ }^{40}$. Penyakit penyerta atau komplikasi juga dapat berpengaruh terhadap prognosis penyakit CAP, bahkan dapat menyebabkan kematian apabila tidak diterapi dengan tepat ${ }^{23}$. Status gizi yang kurang atau malnutrisi dapat menyebabkan penurunan daya tahan tubuh, salah satunya akibat penurunan $\operatorname{IgA}$ yang berfungsi melindungi saluran nafas atas dari infeksi organisme patogenik sehingga dapat memperparah kondisi infeksi saluran nafas $^{20,21}$. Hasil uji statistik pada Tabel VII menunjukkan tidak ada hubungan yang siginifikan antara ketiga variabel perancu terhadap luaran klinis (nilai $\mathrm{p}>0,05$ ).

Kelebihan penelitian ini yaitu tidak hanya melihat rasionalitas antibiotik namun juga melihat hubungan rasionalitas tersebut terhadap luaran klinis yang diperoleh, selain itu evaluasi rasionalitas antibiotik menggunakan kategori Gyssens sehingga ketidakrasionalan antibiotik yang terjadi dapat diketahui secara jelas berada pada kategori mana, sedangkan kelemahan penelitian yaitu pengambilan data dilakukan secara retrospektif, tidak melihat langsung 
Tabel VII. Hubungan Variabel Perancu terhadap Luaran Klinis

\begin{tabular}{|c|c|c|c|c|c|}
\hline \multirow{3}{*}{ Karakteristik } & \multicolumn{4}{|c|}{$\begin{array}{l}\text { Luaran Klinis } \\
(\mathrm{n}=73 \text { pasien })\end{array}$} & \multirow{3}{*}{$P$} \\
\hline & \multicolumn{2}{|c|}{ Baik } & \multicolumn{2}{|c|}{ Belum Baik } & \\
\hline & $\mathbf{n}$ & $(\%)$ & $\mathbf{n}$ & $(\%)$ & \\
\hline \multicolumn{6}{|l|}{ Usia } \\
\hline 0 bulan -5 tahun & 67 & $(95,7)$ & 3 & $(4,3)$ & \multirow{2}{*}{$0,158^{*}$} \\
\hline$>5$ tahun & 2 & $(66,7)$ & 1 & $(33,3)$ & \\
\hline \multicolumn{6}{|l|}{ Infeksi Penyerta } \\
\hline Ada & 11 & $(84,6)$ & 2 & $(15,4)$ & \multirow[t]{2}{*}{$0,143^{*}$} \\
\hline Tidak & 58 & $(96,7)$ & 1 & $(3,3)$ & \\
\hline \multicolumn{6}{|l|}{ Penyakit Penyerta non infeksi } \\
\hline Ada & 60 & $(93,8)$ & 4 & $(6,3)$ & \multirow[t]{2}{*}{$1,000^{*}$} \\
\hline Tidak & 9 & $(100)$ & 0 & $(0)$ & \\
\hline \multicolumn{6}{|l|}{ Status gizi } \\
\hline Baik & 31 & $(100)$ & 0 & $(0)$ & \multirow[t]{2}{*}{$0,132^{*}$} \\
\hline Kurang/ buruk & 38 & $(90,5)$ & 4 & $(9,5)$ & \\
\hline
\end{tabular}

Keterangan: *data dianalisis menggunakan uji Fisher's

kondisi klinis pasian dan alasan pemilihan antibiotik sehingga penentuan luaran klinis didasarkan pada keputusan klinisi pada hasil rontgen toraks, laju pernapasan dan/atau saturasi oksigen sesuai yang tercantum pada rekam medis.

\section{KESIMPULAN}

Rasionalitas penggunaan antibiotik empiris pada pasien anak dengan CAP di rawat inap RSUP Dr. Sardjito Yogyakarta dievaluasi menggunakan kategori Gyssens menunjukkan bahwa sebanyak 76,5\% (101 regimen) antibiotik empiris yang diberikan rasional. Hasil analisis statistik menunjukkan bahwa pemberian antibiotik empiris secara rasional pada pasien anak CAP meningkatkan perbaikan luaran klinis ( $\mathrm{p}=0,011$; $\mathrm{OR}=2,957$; $95 \% \mathrm{CI}=1,263-6,923)$.

\section{UCAPAN TERIMA KASIH}

Penulis mengucapkan terimakasih kepada RSUP Dr. Sardjito Yogyakarta dan Fakultas Farmasi, Universitas Gadjah Mada Yogyakarta, serta semua pihak yang terlibat selama proses penelitian. Penulis tidak memiliki konflik interest terhadap instansi yang terlibat dalam penelitian.

\section{DAFTAR PUSTAKA}

1. Anand N., Kollef MH. The alphabet soup of pneumonia: CAP, HAP, HCAP, NHAP, and VAP. Semin Respir Crit Care Med. 2009;30(1):3-9.

2. Kementerian Kesehatan Republik Indonesia. Profil Kesehatan Indonesia Tahun 2015. Jakarta: Kemenkes RI; 2016.

3. Perhimpunan Dokter Paru Indonesia. Pneumonia Komuniti, Pedoman Diagnosis $\mathcal{E}$ Penatalaksanaan Di Indonesia. Jakarta: PDPI; 2003.

4. Burnham JP., Kollef MH. CAP, HCAP, HAP, VAP: The Diachronic Linguistics of Pneumonia. Chest. 2017;152(5):909910.

5. Kementerian Kesehatan Republik Indonesia. Riset Kesehatan Dasar 2013. Jakarta: Kemenkes RI; 2013.

6. UNICEF. One Is Too Many: Ending Child Deaths From Pneumonia And Diarrhoea. New York: UNICEF; 2016.

7. Kementerian Kesehatan Republik Indonesia. Profil Kesehatan Indonesia Tahun 2016. Jakarta: Kemenkes RI; 2017.

8. Bradley JS, Byington CL, Shah SS, et al., The Management of CommunityAcquired Pneumonia in Infants and 
Children Older Than 3 Months of Age: Clinical Practice Guidelines by the Pediatric Infectious Diseases Society and the Infectious Diseases Society of America. Clin Infect Dis. 2011;53(7):2576.

9. Rodrigues CMC. Challenges of Empirical Antibiotic Therapy for Community-Acquired Pneumonia in Children. Curr Ther Res Clin Exp. 2017;84:7-11.

10. Batchelor HK, Marriott JF. Paediatric pharmacokinetics: Key considerations. Br J Clin Pharmacol. 2015;79(3):395-404.

11. Mi X, Li W, Zhang L, et al., The drug use to treat community-acquired pneumonia in children: A crosssectional study in China. Medicine (Baltimore). 2018;97(46):13224.

12. Rosdiana D, Anggraini D, Balmas M, Effendi D, Bet A. Peningkatan Rasionalitas Penggunaan Antibiotik Pasca Implementasi Kebijakan Penggunaan Antimikroba di RSUD Arifin Achmad Pekanbaru. J Kedokt Brawijaya. 2018;30(1):36-40.

13. Ventola CL. The Antibiotic Resistance Crisis. Pharm Ther. 2015;40(4):277-283.

14. Llor C, Bjerrum L. Antimicrobial resistance: Risk associated with antibiotic overuse and initiatives to reduce the problem. Ther Adv Drug Saf. 2014;5(6):229-241.

15. Corbett A, Golembiewski J, Gonzales J, Johnson S. Lexicomp -Drug Information Handbook 26th Edition. New York: Wolters Kluwer; 2017.

16. Fuseini H, Newcomb DC. Mechanisms driving gender differences in asthma. Curr Allergy Asthma Rep. 2017;17(3):19.

17. Yung JA, Fuseini H, Newcomb DC. Hormones, sex, and asthma. Ann Allergy Asthma Immunol. 2018;120(5):488-494.

18. Hartati S. Analisis faktor risiko yang berhubungan dengan kejadian pneumonia pada anak balita di RSUD Pasar Rebo Jakarta,. 2011.
19. Kartasasmita CB. Pneumonia Pembunuh Balita. Bul Jendela Epidemiol. 2010;3:22-26.

20. Artawan A, Purniti PS, Sidiartha IGL. Hubungan antara Status Nutrisi dengan Derajat Keparahan Pneumonia pada Pasien Anak di RSUP Sanglah. Sari Pediatri. 2016;17(6):418-422.

21. Rodríguez L, Cervantes E, Ortiz R. Malnutrition and gastrointestinal and respiratory infections in children: A public health problem. Int J Environ Res Public Health. 2011;8(4):1174-1205.

22. Ikatan Dokter Anak Indonesia. Pedoman Pelayanan Medis. Jakarta: Ikatan Dokter Anak Indonesia; 2009.

23. Lodha R, Randev S, Kabra SK. Oral antibiotics for community-acquired pneumonia with chest-indrawing in children aged below five years: A Systematic Review. Indian Pediatr. 2016;53(6):489-495.

24. Torres A, Peetermans WE, Viegi G, Blasi F. Risk factors for community-acquired pneumonia in adults in Europe: A literature review. Thorax. 2013;68(11):1057-1065.

25. Stuckey-Schrock K, Hayes BL, George CM. Community-Acquired Pneumonia in Children. Am Fam Physician. 2012;86(7):661-667.

26. Aryani DE, Hasmono D, Zairina N, Setiawan L. ANALYSIS OF ANTIBIOTICS USE IN PEDIATRIC PNEUMONIA PATIENTS AGED 3 MONTHS - 5 YEARS. Folia Medica Indones. 2017;52(2):108-115.

27. da Fonseca Lima EJ, Lima DEP, Serra GHC, Abreu e Lima MAZS, de Mello MJG. Prescription of antibiotics in community-acquired pneumonia in children: Are we following the recommendations? Ther Clin Risk Manag. 2016;12:983-988.

28. Queen MA, Myers AL, Hall M, et al., Comparative effectiveness of empiric antibiotics for community-acquired pneumonia. Pediatrics. 2014;133(1):e2329. 
29. Kementerian Kesehatan Republik Indonesia. Peraturan Menteri Kesehatan Republik Indonesia Nomor 2406/MENKES/PER/XII/2011 Tentang Pedoman Umum Penggunaan Antibiotik. Jakarta: Kemenkes RI; 2011.

30. Leekha S, Terrell CL, Edson RS. General Principles of Antimicrobial Therapy. Mayo Clin Proc. 2011;86(2):156-167.

31. Radji M. Mekanisme Aksi Molekuler Antibiotik Dan Kemoterapi. Jakarta: EGC; 2017.

32. Harris M, Clark J, Coote N, et al., British Thoracic Society guidelines for the management of community acquired pneumonia in children: Update 2011. Thorax. 2011;66(Suppl 2):1-23.

33. Ambroggio, Test, Metlay. Beta-lactam versus Beta- lactam/macrolide Therapy in Pediatric Outpatient Pneumonia. Pediatr Pulmonol. 2016;51(5):541-8. https://www.ncbi.nlm.nih.gov/pubmed /26367389. Accessed July 1, 2019.

34. World Health Organization. Buku Saku Pelayanan Kesehatan Anak Di Rumah Sakit, Pedoman Bagi Rumah Sakit Rujukan Tingkat Pertama Di Kabupaten/ Kota. WHO; 2009.

35. Badminton MN, Bailey S, Bates GDL,
Bedford H. BNF for Children 20172018 Edition. London,UK: BMJ Group; 2017.

36. Tim PPRA. Panduan Penggunaan Antibiotik RSUP Dr. Sardjito. Yogyakarta, Indonesia: PPRA RSUP Dr. Sardjito; 2017.

37. Handayani RS, Siahaan S, Herman M. Antimicrobial Resistance and Its Control Policy Implementation in Hospital in Indonesia. J Penelit Dan Pengemb Pelayanan Kesehat. 2017;Vol. 1, No. 2:131-140.

38. Asín-Prieto E, Rodríguez-Gascón A, Isla A. Applications of the pharmacokinetic/pharmacodynamic (PK/PD) analysis of antimicrobial agents. I Infect Chemother Off J Jpn Soc Chemother. 2015;21(5):319-329.

39. Rahayu YD, Wahyono D, Mustofa. Evaluasi Rasionalitas Penggunaan Antibiotik Terhadap Luaran Pada Pasien Anak Penderita Pneumonia. J Manaj Dan Pelayanan Farm. 2014;4(4):264-270.

40. PrabhuDas M, Adkins B, Gans H, et al., Challenges in infant immunity: Implications for responses to infection and vaccines. Nat Immunol. 2011;12:189194. 